\title{
Overview and synthesis
}

\section{Benno Ferrarini, Marcelo M. Giugale, and Juan J. Pradelli ${ }^{1}$}

\section{INTRODUCTION AND CONTEXT}

For the past five decades, the world has marveled at the fast, sustained, and poverty-reducing growth of the Asian economies. Since the early days of Japan's export-led strategy and the success of the Southeast Asian "tigers" to the rise of the People's Republic of China (PRC) and India, the region has shown what is possible in economic development. Along the way, it became a core engine of the world's economy, a key pillar of financial stability, and a major component of geopolitical balance. Today, keeping Asia growing is a matter of global importance.

The sustainability of Asia's growth depends, of course, on many factors. Some, like environmental protection and social inclusion, have been the focus of much attention and analysis. Others, like good management and cultural norms, are seen as specific to each country. But there is one crucial factor that is less understood and runs through the entire Asian economic narrative: debt. Governments, firms, and households have borrowed, and continue to borrow, their way to prosperity. The outbreak and aftermath of the coronavirus disease (COVID-19) will only accelerate that process. Is this sustainable? And what needs to be done to keep it sustainable? These are the central questions addressed in this book.

In a collection of 16 commissioned essays by renowned experts and practitioners, this book studies the anatomy and dynamics of debt accumulation in Asia (before and after the pandemic), the incentives of all those involved (financiers, families, private corporations, public enterprises, ministers, municipalities, regulators, and many more), and the options that policy makers have to keep debt in check.

The approach is factual, analytical, and practical — what actually happened, why it happened, which policies have been tried and worked and which ones have not, and what should be done next. This allows for deep dives into subregional, country, and sector cases that provide rich lessons for others. How come Japan's public debt is so large and still so seemingly sustainable? What does the PRC's great rebalance from investment to consumption mean for the debt of its corporations, provinces, and municipalities? How best should small or poor or isolated Asian countries be financed? Can fiscal deficits be reined in, fiscal space created, and fiscal risks hedged, especially after the struggle with the COVID-19 outbreak? Where will the money come from when Asia's population grows older and more dependent?

These are the kind of issues this volume dissects and debates to explore the sustainability of Asia's debt. But it also explores the new instruments that policy makers have at their disposal to tackle those issues - instruments they did not have only a decade ago. Think of 
the creation of fiscal space by targeting energy subsidies through biometric identification and mobile finance. Or the hedging of fiscal risk through market insurance. Or the diversification of financing sources through thematic bonds. These are some of the largely untapped options that Asian policy makers and public debt managers have.

A final word on timing. Before COVID-19, actionable knowledge of Asia's debt would have been important. After COVID-19, it will be even more urgent. As progress with cures and vaccination combats the virus, governments and corporations will have to deal with the debt they ran up to pay their way through the crisis - a buildup on top of an already large pile. The reckoning and the rush for policy solutions will likely accelerate in the second half of 2022 and will last for several years. That is why this book is published now.

\section{THE MAIN MESSAGES}

Whether one looks across the entire region in all its vast diversity, at groups of countries of similar income or geography, or at individual economies, there is no question that Asia has been borrowing fast. This is true whether the debtors are governments, corporations, households, or subnationals. Every sector has tapped finance with gusto. Debt burdens - that is, debts as a percentage of gross domestic product (GDP) - have grown large, and at times, massive. ${ }^{2}$ The pandemic has made them much worse.

And yet, for a number of reasons, the debt seems sustainable, at least for now. Those reasons span widely. Learning from previous crises, high- and middle-income Asia developed its domestic capital market and shifted to it most or all of its public borrowing. Others undertook or are undertaking painful structural reforms. Donors, notably bilaterals, have been generous with low-income and island-state countries. And global investors still see the region as a good bet, particularly when interest rates in advanced economies are close to zero.

But sustainable does not mean riskless. Behind the causes for comfort, there are significant dangers. To start with, Asia's fiscal space - that is, its capacity to accommodate additional unforeseen expenses in a financially sound way-has shrunk and is bound to shrink further. If economic growth does not return soon to its rapid long-term path, it is difficult to see how the post-pandemic reconstruction will be funded. Then there is the question of contingent liabilities. By law or by necessity, Asian central governments are, or are expected to be, responsible for the obligations of other entities, public and private. The values at stake sometimes dwarf those governments' own debt. Finally, there is the debt-equivalent to an elephant in the room: aging. Societies in East Asia are growing old so quickly that, short of major reforms or a technological miracle, their public debts will be multiples of their current levels. The beginning of this surge is only 20 years away. And all this assumes that forecasting the region's fiscal accounts can be done accurately-it can't. While not worse than elsewhere, projections for the evolution of fiscal deficits and public debt in Asia just one or two years out rarely pan out. The volatility of budgets is too high.

What should Asia's policy makers do about a debt burden that is huge, growing, risky, sustainable today, and unsustainable in the future? In a nutshell, they should build on their successes, put in motion today the reforms that will defuse a crisis in the future, and tap into new instruments. The region's public debt managers - and, more generally, financial sector authorities - have much to be proud of. Their efforts to develop domestic capital markets have become a key asset and should be furthered and extended to lagging countries. Those manag- 
ers have begun to wrestle with contingent liabilities - more than anything by bringing them out in the open. And they have started to create national awareness about the cost and realism of price subsidies and social security promises. On both fronts, the time for action has come.

Looking forward, fiscal risks - natural, operational, financial, commodity, and otherscapable of derailing public borrowing plans can be reported more accurately and addressed more thoroughly. In fact, Asian governments can now buy insurance against those risks, directly from investors or through multilateral banks. They should leverage the market for impact finance, in particular for thematic bonds (green, blue, social, gender, etc.). This market has become a major alternative source of funding for countries and companies ready to make commitments on the use of the proceeds. Not all of these instruments currently fit all countries, because financial standing and institutional capacities differ. But the menu is ample and flexible.

Diagnosis, risks, policies - these three angles on Asia's debt provide the structure of this Overview and synthesis. In what follows, the substance of each chapter is distilled and threaded into that structure. Those chapters are the source and reference for the data presented here. The analysis draws on the experience of economies across the region, and identifies challenges and opportunities.

\section{A DIAGNOSIS OF ASIA'S DEBT}

The analysis of debt in a region as diverse as Asia calls for both the evaluation of aggregates and the study of countries and sectors. Part I offers both. It starts with a description of trends, outcomes and forecasts, in both public and private financing. It then digs deeper and draws lessons from the two regional giants - Japan and the PRC - and from the lower-income countries, including those in the Pacific. It completes the picture by looking at the behavior of borrowers over which central governments have only indirect control-corporates, households and subnationals.

\subsection{Debt's Anatomy: Asia Before and After COVID-19}

From the point of view of debt, there are many Asias. Data can be cut by levels, geography, vulnerability, or even institutional capacity. A further categorization can be crafted around the economies' relationship with the Asian Development Bank (ADB). Within Asia, this includes Japan, as well as a broad and heterogenous group of ADB's 49 regional members-which range from the PRC, the Republic of Korea (ROK), and India to Armenia, Fiji, and Maldives. ${ }^{3}$

With those definitions in mind, five stylized facts could be established at the end of 2019that is, before the pandemic. First, Asia as a whole accounted for about a third of the world's public debt, some $\$ 25$ trillion out of $\$ 72$ trillion. About half of that $\$ 25$ trillion was owed by ADB's regional members, and about half of these economies' public debt comes from the PRC.

Second, the public debt burden of developing Asia, measured as the ratio of public debt to GDP, was not exorbitant for global standards - 53 percent, compared with a world average of 75 percent, and more than 100 percent in advanced economies.

Third, while their public indebtedness was relatively modest, ADB's 49 regional members led the world in private debt. It stood at almost $\$ 38$ trillion. Nonfinancial corporations owed just over two-thirds of that ( $\$ 26$ trillion). And four-fifths of that corporate debt (\$21 trillion) 
was owed by Chinese firms. Behind those absolute values, there was also a world-topping burden: the private debt of ADB's regional members was equivalent to more than 170 percent of their GDP. Again, the PRC and its nonfinancial corporates carried more than half of it.

Fourth, Asia, and its ADB's regional members in particular, were not always this indebted. Their public and private sectors went on a borrowing spree after the global financial crisis of 2008. Just before COVID-19 arrived, there were signs of moderation, driven mainly by the PRC's effort at supply-side structural reform - as it will be described later on. When the virus arrived, heavy borrowing returned.

And fifth, there was - and there still is - a relieving feature in Asia's total debt: only a small portion ( $\$ 8$ trillion out of some $\$ 70$ trillion) is external, that is, owed to nonresidents and in foreign currencies. This is essentially due to the unparalleled ability of Japan's government and the PRC's corporations to finance themselves locally and, to a lesser extent, efforts of other emerging countries to develop their domestic capital markets.

So, overall, until the end of 2019 , Asia's debt problem was not the traditional-Latin American? - one of governments overborrowing in foreign currency and heavily depending on global investors to keep them afloat. That "overall" comfort hid a good deal of fiscal vulnerability and country heterogeneity. On the one hand, since the global financial crisis of 2008, economic growth in the ADB's regional members had been falling (from over 8 percent to less than 6 percent per year on average), fiscal balances had been deteriorating (from an average deficit of 1.4 percent of GDP to almost 4 percent), and saving and investment had remained stagnant (albeit still at a high level of about 35 percent of GDP). On the other hand, most governments in lower-income countries, including in the Pacific, and countries in the Caucasus and Central Asia had bucked the region's trend and had grown more dependent on external funding, at a time when their current accounts were deteriorating and their international reserves were dwindling. For the Caucasus and Central Asia, the problem was double: not only had their governments borrowed in foreign currency, so had their private sectors - in some cases by more.

Along came COVID-19 and warning lights began to appear in Asia's debt radar. The ADB's regional members added $\$ 1.6$ trillion to their collective fiscal deficit in 2020 - and will have added more in 2021. That is on a par with the rest of the world-except for the much higher United States (US). By the beginning of 2022, the simple average public debt in ADB's regional members will be almost 9 percentage points of GDP higher. A fifth of those governments (Bhutan, Fiji, the Lao People's Democratic Republic [Lao PDR], Maldives, Mongolia, India, Pakistan, and Sri Lanka) will be above the "high scrutiny" threshold of the International Monetary Fund (IMF) for public debt monitoring, that is, they will have debts worth 70 percent of GDP or more.

More of concern, those high-scrutiny countries (minus India), the small Pacific island states, and the nations in the Caucasus and Central Asia will continue to depend-perhaps more heavily - on external financing to cover their public financing needs. They cannot develop their domestic capital markets fast enough. And, in places like Georgia, Kazakhstan, or the Kyrgyz Republic, the (in)ability of governments to raise funds abroad at reasonable rates will have a direct impact on the financial viability of their corporate sectors, where much of the external debt sits.

Outer years do not look much better for countries with public debts above 70 percent of GDP. Even if growth averages 4 percent per year over the next four years - a solid recovery- 
their governments' indebtedness will not come below or significantly below that threshold. They will not be alone in their financial predicament. Only three ADB regional members are expected to shave 10 percentage points of GDP or more from their public debt ratios in the medium term - and that assumes that the economic rebound and fiscal consolidation both happen.

In sum, Asia as a whole, or as its developing Asia cohort, is in a sobering debt position, one which is best understood through the lens of countries and sectors. At one end are Japan and the PRC with their towering debts and their ability to borrow in local currency. At the other end is a group of low- and middle-income countries dealing with high indebtedness, acute external dependence, or both. In the same vein, the borrowing behavior of governments has been quite different from that of corporations, households and, less obvious, subnationals. The following subsections investigate each of these cases.

\subsection{Japan's Public Debt: A Case of Irreplicable Sustainability}

Mention a country whose public debt is twice as big as its GDP and any investor would worry. Say that the debt was growing fast and, because of a pandemic, it will now grow even faster, and you should expect a bond sell-off and a downgrade in credit rating. That is what Finance 101 would predict. Not, it seems, if the country is Japan. What lies behind that gravity-defying resilience? Two factors: the debt is denominated in yen - the local currency-and its interest rate is lower than the economy's rate of growth. This means that to stabilize or reduce the ratio of debt to GDP, the Japanese government does not need major cuts in its fiscal deficit. The adjustment is feasible, politically or otherwise. Ergo, investors feel comfortable.

Basic simulations show the point. The key variables are the interest rate, the nominal growth rate, and the primary fiscal balance. Initially, abstract from COVID-19 and assume that nominal growth stays at 1.5 percent per year over the medium term-a conservative assumption. Now think of three scenarios for annual nominal interest rates: zero (close to today's), 1 percent, and 2 percent. In these cases, Japan can put its debt stock as a percentage of GDP on a steep downward path even if it did little fiscal "consolidation"-with expenditures growing at half the speed of revenues. To be sure, that debt would still be between 100 percent and 160 percent of GDP in 2050, that is, large but much less than today and declining. Conversely, if interest rates stayed around zero, the debt ratio would stay constant even if the government ran an annual primary fiscal deficit equal to 3 percent of GDP.

Interestingly, those trends are not affected by the economic and fiscal impacts of the pandemic - only their starting points are. The stimulus package applied by the Japanese government in 2020 swelled its primary deficit by 10 percent of GDP and its debt ratio by 25 percentage points. But, if the recovery means returning to previous levels of fiscal consolidation and growth by the end of 2021, the long-term fall in the debt burden for our three interest rate scenarios holds.

The magic behind this arithmetic is the premise that growth will top interest rates. Will that be the case post-COVID-19? There are arguments both ways. If the health crisis lingers on, it may permanently reduce human and physical capital — it could "scar" the economy. This would certainly dampen long-term growth. But it is also possible that the pandemic may force a faster and broader adoption of technology, even for Japanese standards-remote working, artificial intelligence, robotics, digitalization, and others. This, if it happens, should raise pro- 
ductivity and, thus, growth. Similarly, it is unclear which way interest rates will go in Japan. They may fall if the virus scares consumers into saving more. Or they may rise if, because of its much larger absolute size, public debt crowds out private investment.

But, if growth falls below interest rates, would buyers of Japanese public bonds retrench at the sight of a rising debt burden? Unlikely. For two main reasons. First, with corporate and individual income tax rates that are low for the standards of advanced economies, more fiscal austerity is doable. Second, and ultimately, those bonds are denominated in a currency the government can print and the Japanese people want to hold. In fact, measured by a narrow definition of money (known as "M1"), Japanese hold yen worth about 160 percent of GDP. This is a world-beating level of confidence in your own currency. Not many countries in Asia or elsewhere can count on that. By comparison, Koreans hold won worth about half of their GDP, not unlike Britons, Canadians, and Danes do with the pound, the loonie, and the krone. The corresponding number for Americans and the dollar is "just" 30 percent.

While this "home bias" makes Japan's debt situation unique — and its sustainability difficult to replicate - there is another country characteristic that points in the opposite direction. The Japanese nation is aging at high speed, something that, without reforms, could make the debt sky-high and unbearable. This long-term risk, which is happening in other Asian countries too, is analyzed in section 4 below.

\subsection{The PRC: Corporate Debt as a Tool for Macroeconomic Management}

The size and sustainability of debt in the Chinese economy matters well beyond the PRC. It could condition growth and financial stability around the world, especially in commodity-exporting countries. The numbers are staggering: the country's total debt soared from 141 percent of GDP in 2008 to 243 percent of GDP by the end of 2019. That is approximately a $\$ 30$ trillion jump-equivalent to about a third of today's global GDP. Much of the jump was a policy response to the 2008-2009 global financial crisis, arguably the right macroeconomic response. As the recovery gained traction though, an effort to rein back on borrowing was launched in 2015. Enter COVID-19 with its enormous financing needs and the question now is: will the indebtedness, swollen by the pandemic, be sustainable? To answer, one needs to dissect the numbers.

The first observation is that central-government or external debt is not the problem. They are relatively low and stable. In contrast, local governments, special-purpose vehicles, and households all borrowed heavily and face sizable local-currency liabilities. But, by far, the main drivers of the PRC's debt have been nonfinancial corporations. In the past 12 years, their liabilities rose by more than 50 percentage points of GDP, and now stand at more than 150 percent of the PRC's GDP. No other country experienced anything remotely similar. In fact, in the US, the epicenter of the global financial crisis, the debt burden of corporations and households has remained stable or has fallen since 2009.

But, digging deeper into a database of 4 million Chinese industrial companies, reveals that the buildup of the PRC's corporate debt has two distinctive marks. First, it is concentrated in a very small fraction of firms - probably less than a thousand - which happen to be large, state-controlled, and listed on the stock exchange. In contrast, the rest of the corporate sector has been deleveraging over the last 10 years and, sensibly, shed mostly short-term debt. Second, almost all that debt is owed to local state-owned banks, not to bondholders. This 
linked the commercial fate of those companies to individual depositors and limited the tradability of the claims.

Chinese policy makers understood early on the systemic implications of the dangerous debt accumulation that was taking place at the core of the country's corporate sector. Their response was to launch, in November 2015, a program of "supply-side structural reform". The idea was to expose deeply indebted firms to the market discipline of consumers, creditors, and competitors. In parallel, government support would be trimmed back, and unviable- - "zombie"-firms would be left to exit through bankruptcy. This, the argument went, would raise total factor productivity, increase profitability, and make corporate debt more sustainable. All the main economic institutions - from the ministry of finance and the central bank to the insurance regulator and the stock market authority-issued follow-up declarations and directives to speed up and smooth the deleveraging process. More broadly, supply-side reform became a code name for the PRC's new development model, one based on climbing the technological value chain while shifting resources from investment to consumption.

Has it worked? Up until COVID-19, there were encouraging signs. Excess and outdated industrial capacity had been reduced. Efficiency indicators like inventory turnover time had improved. So had indicators of profitability like return on assets and return on equity. A slew of closures, mergers, acquisitions, privatizations ("mixed ownership"), debt restructurings, and debt-for-equity swaps cut the absolute value of debt across the corporate sector. The average interest coverage ratio - a gauge for a firm's ability to service debt - of state-controlled enterprises rose significantly. Will the pandemic derail this progress?

The PRC was quick to control and prevent the spread of the virus. But the quarantines and lockdowns made its GDP tumble - to the tune of almost -7 percent year on year in the first quarter of 2020. The central government, like governments everywhere, responded with unprecedented fiscal and monetary stimuli. Tax cuts, looser credit, and targeted loans were all deployed. Local governments issued a new generation of bonds to build infrastructure. Even "shopping vouchers" for consumers were on the policy menu. While saving the economy in the short term, emergency corporate lifelines go against the grain of the supply-side structural reforms. Whether those reforms are quickly resumed, suspended for a while, or abandoned forever will determine whether the PRC's debt problem returns to a path toward sustainability or not.

\subsection{Asia's Lower-Income Countries: Concessional Debt, Concessional Rescues}

Governments in Asia's lower-income countries - those elsewhere known as low income or lower-middle income - did not sit out the wave of borrowing that dominated the last decade. By early 2020, the wave was already coming to an end, forced by an accumulation of fiscal and external imbalances. That year, the IMF reported that, of the 21 Asian lower-income economies, the risk of public debt distress was high in 12 and moderate in four-a major deterioration from five years before. ${ }^{4}$ While differences across countries exist, the deterioration was caused by a mix of quantity and quality: not only did debt levels rise (on average, by 11 percentage points of GDP over the past 10 years) but the composition of that debt became more problematic (more from private lenders, more non-concessional, more foreign currency, and shorter term). ${ }^{5}$ In a way, developing Asia never did what emerging Asia did after its crisis of the mid-1990s: it did not switch its marginal source of finance from foreign 
to domestic currency. It probably couldn't, as its local capital markets stayed too small and too underdeveloped.

A certain level of comfort is found in the fact that, for those 21 countries, the large majority of public external debt is still with the ADB and other multilaterals, and with non-Paris Club bilaterals (like the PRC, India, and United Arab Emirates). Their loans are easier to roll over than traded bonds. But COVID-19, with its brutal impact on growth and fiscal balances, is likely to destabilize the financial position of many, if not most, of developing Asia. If it does, what should be done?

Debt booms and busts are not new, and each cycle has left important lessons. Latin America (borrowing in the 1970s and defaults in the early 1980s), Africa (late 1980s and mid-1990s), East Asia (early 1990s and late 1990s), and Europe (early 2000s and late 2000s), all left a mark. They taught us five main lessons. First, crises come suddenly and their effects on output last for a long time. Second, the pain of debt distress and default can be brutal but is rapidly forgotten, and countries tend to go back to borrowing before fundamental reforms to make the new debt sustainable are put in place-witness the bond issues by African governments over the past five years. Third, heavy borrowing in foreign currency does not mix well with rigid foreign-exchange regimes - it was the abandonment of Thailand's peg that triggered the crisis in East Asia. Fourth, private lenders are generous when global financial conditions make them search for yield, but quickly withdraw at first sight of international or local trouble. And fifth, debt restructuring is a messy process, and is even messier when it involves private creditors. Official lenders usually have political incentives to organize themselves and write off (or not write off) debt; the Paris Club is a reflection of that. Private bondholders, on the other hand, have an incentive to hold out. The existence of collective action clauses to force them to cooperate has, in practice, produced mixed results.

Keeping those lessons in mind, and knowing that the pandemic calls for large, additional public expenditures, how should governments in developing Asia be financed? The answer is not straightforward because, as mentioned before, most of these governments were already at a high risk of debt distress. For them, balancing debt sustainability and paying for response and recovery point to only one kind of solution, at least in the short term: concessional financing, whether as grants, loans, guarantees, or voluntary relief, all of them with no or light conditions attached. This would provide liquidity to afford health expenses, social protection, and economic stimulus. It would also implicitly help roll over amortizations and avoid macroeconomic adjustments in the midst of a deep recession.

However, concessional financing can realistically come only from official creditors. Private ones would implicitly benefit from it - they would be effectively bailed out, at least in part. That is not easy to arrange or accept. It has been the weakness at the core of the Debt Service Suspension Initiative put forward by the G20 and the Paris Club in the beginning of the pandemic. Many countries declined the offer, fearful of being perceived or rated as heightened default risks. The G20 and the Paris Club also launched a Common Framework for debt restructuring to which all official creditors (including the PRC), but no private investors have committed. Others, like the United Nations Conference on Trade and Development, have called for more radical solutions, like automatic debt standstills and international agreements to deter judicial action in all jurisdictions against defaulting governments - a proposal that would in practice lock those governments out of the market. Intermediate solutions have also been proposed, whereby private lenders accept delays or even partial write-offs if there is 
external verification - through a facility at the World Bank or at other multilaterals - that the freed-up funds are used only for pandemic-related expenses.

No matter how it is tackled, the problem of uneven burden sharing between official and private creditors may be inevitable in low-income countries, including those in Asia. Holding official debt relief until no private bondholders benefit from it would inflict further pain on populations that have already been hurt by a one-in-a-century shock for which they bear no responsibility. So international politics may prevail. In exchange, countries that call for multilateral or bilateral support could and should demonstrate complete debt transparency — when you ask for help, you should be willing to open your books.

Things will be different in the medium- and long term. A mix of domestic resource mobilization, fiscal retrenchment, structural transformation, and innovative financing tools will be the priority. Once the virus is controlled by therapeutics or vaccination, and output recovery is underway, it will be time to remove legal, regulatory, fiscal, infrastructure, and other obstacles to growth. It will also be time to construct the pillars of local financial markets. That is the essence of "building back better". For those that undertake reform, the menu of financing options will widen - to include, among others, thematic bonds, blended impact funds, and government insurance. These instruments heed lessons from previous crises, and temper the tendency toward future binge borrowing.

\subsection{Small Pacific Islands' Debt: Official, Sustainable, and Precarious}

Sometimes, extreme geography just thwarts debt sustainability. This is the case with small island states in the Pacific. Isolated, at the mercy of frequent disasters triggered by natural hazards, and with few and concentrated sources of income, the challenge of financing their development has been difficult in the best of times. In the post-COVID-19 era, it seems unsurmountable - at least in pure market terms. These countries were under financial stress before the pandemic, and many relied on donors to balance their books.

Epidemiologically, the coronavirus had a relatively mild impact on the Pacific islands - the one benefit of a far-off location. But it was economically devastating for these nations that depend almost entirely on tourism, a single commodity, or remittances. Early estimates put the contraction in regional GDP at over 6 percent in 2020, followed by a very slow, protracted recovery-about 1.5 percent per year. Governments reacted with stimulus packages. But the sort and scale of policy responses seen in other parts of the world were not feasible. With foreign aid accounting for a large share of fiscal revenues, and with little or no capacity to borrow abroad, there was not much space for more public spending. And with pegged exchange rates, major loosening in monetary policy was not an option.

Donors did their part. Their combined financial assistance topped $\$ 1.6$ billion, equivalent to about 5 percent of the region's GDP. They suspended debt service (G20), redirected and frontloaded funds (development banks), and came up with fresh funding (IMF, Australia). This helped. But it did not solve the fundamental debt sustainability problem, which the pandemic worsened.

That poses three questions: is a wave of debt crises in the Pacific coming? How much external financing is necessary for the region to recover its growth path? What form should the financing take to avoid financial distress down the road? To answer, it is important to keep in mind that smallness (of land, population, or GDP), remoteness (distance to trading 
partners), internal dispersion (archipelagos), vulnerability (climate), and export concentration (one or two main items) have made financing the development of these islands a unique, perennial, and so-far-unsolved problem - pandemic or not. Their funding gap is structural and colossal - the World Bank puts it at a tenth of GDP per year. Their dependency on aid is thus almost inescapable - to the tune of 9 percent of GDP per year, compared with about 3 percent in sub-Saharan Africa. Their governments' capacity to carry debt is limited, as is their ability to borrow from private lenders in global financial markets.

That aid dependency defuses the imminence of a wave of debt defaults seen in, for example, Latin America in the 1980s. Almost all public external debt of the Pacific islands is owned to official creditors in concessional or "semi-concessional terms", reducing both rollover risk and the cost of debt service. ADB is, by far, their largest lender. The PRC is the second. Workouts, if ever needed, would be easier to arrange. Only Fiji and Papua New Guinea (PNG) have tapped international bond markets. In fact, except for those two countries, the average interest rate on the region's external debt (about 2 percent) is low and below its long-term rate of economic growth - as it should be when almost the entire funding comes from official creditors.

The analysis can be traced to four Pacific countries that account for 90 percent of the region's GDP and whose financial outlooks look the most uncertain: Fiji, PNG, Samoa, and Tonga. A baseline scenario can be built where growth slowly resumes later in 2021 or early 2022. That scenario can then be "shocked" by either a lingering effect of the pandemic on growth, the realization of contingent liabilities (like public guarantees in favor of state-owned enterprises), or severe disasters triggered by natural hazards. The conclusion is that debt sustainability - defined as stable or declining public debt-to-GDP ratios-is possible but precarious.

For example, if no further shock occurs, Fiji's government needs to maintain a modest primary fiscal surplus of at least 0.3 percent of GDP — doable, by its past standards. To be sure, debt would be much higher than its pre-pandemic level but it would stabilize, at about 80 percent of GDP. Should the recovery in tourism be delayed even by a year, or another cyclone like Winston happens, or the guarantees given to Fiji Airlines be called, debt will jump to 100 percent or above of GDP - much more if those shocks came together. That would call for a fiscal consolidation for which the country has no track record.

A similar conclusion-precarious but sustainable debt position-applies to PNG, but for different reasons. The pandemic found the country with relatively low levels of public debt (around 40 percent of GDP). About two-thirds of it is in foreign currency, but in semi-concessional terms. The weakness is in the short maturity of the domestic portion of that debt, and the associated rollover risk. But the government's solvency is not at issue. What could derail this benign prognosis? A slower post-COVID-19 recovery, currency depreciation, or bailouts for state-owned enterprises could all hike the initial level of debt, but not to a level that moderate fiscal effort could not correct in the long term. This points to the main concern: if, instead of improving, the primary fiscal balance returned to its lax trend of the past decade (about 2.3 percent of GDP in the red), the burden of public debt will grow-not explosively, but significantly.

The same message applies to Samoa and Tonga. Both entered the COVID-19 crisis in weak economic and fiscal positions - they had experienced, respectively, a severe measles outbreak and consecutive cyclones. Both were considered at high risk of being debt distressed, notably by the IMF. But that assumes that both governments will not be able to bring much discipline 
to their accounts (long-term primary deficits averaging over 5 percent of GDP in Samoa and just under 1 percent in Tonga). Looking at the countries' performance over the last 20 years, they did, can, and should do better than that, even accounting for the cost of disasters caused by natural hazards. Just by returning their fiscal position to the past average, they would bring their debt burdens under control. The debt-to-GDP ratio would stabilize in Samoa and decline in Tonga.

These simulations highlight the absolutely central role that fiscal policy plays in small island states. It also hints at the criticality of concessional financing. Loading governments with expensive debt, even if they have market access, weakens their primary balances, and quickly renders their overall debt unsustainable. In a way, trying to accelerate development by borrowing more in more expensive terms, ends up slowing it. This is relevant in the aftermath of the pandemic, with its urgent search for ways to fund recovery packages. Multilateral banks and bilateral donors are the obvious choice. But how big does their help need to be?

The evidence shows that the "multiplier" effect on growth of an additional dollar of public spending in small islands is small. This has to do with import dependency and institutional capacity. Using multipliers of 1 or 1.5 , and recovery packages worth between 1.8 percent and 2.7 percent of GDP in each of the next three years, would bring the Pacific region's GDP to the upward trajectory it was on in 2019 by the end of the decade. That would call for an injection in the range of $\$ 2.3$ billion to $\$ 3.5$ billion over the next three years. That injection would not affect debt sustainability, if it came either as grants or in semi-concessional terms (like those of multilateral banks, the PRC's EXIM bank, or Australia's bilateral loans). Rather, the "growth dividend" of that financing would put long-term debt in the Pacific on a declining path.

\subsection{Asia's Corporate Debt: Lack of Transparency Drives Financial Volatility}

The East Asian miracle - rapid, sustained, and inclusive growth for over three uninterrupted decades - came to a sudden halt in 1997. That year, a financial crisis raced across the East and Southeast Asian economies. What caused the crisis were years of excessive corporate borrowing in the wrong currency. The policy response was predictable: monetary and fiscal policies were tightened, banks were closed or recapitalized and put under more rigorous regulation and supervision, and corporate laws were reformed to ease exit and improve governance.

The new discipline brought about a long period of corporate deleveraging. More importantly, it ended large foreign-currency exposures in both banks and firms. Both changes served the subregion well in 2008 , when the global financial crisis broke out. From the ROK to Thailand, growth recovered its pre-crisis paths within a year or two, and bank solvency indicators did not deteriorate.

The difference in outcomes between the events of 1997 and 2008 raises a logical question: is corporate debt a systemically destabilizing factor for Asia's growth and financial stability? The answer is important for two reasons. First, several Asian countries (notably, the PRC) have, since 2010, seen a sharp resumption in borrowing by firms, albeit in local currency. Second, the region now faces the consequences of a much bigger crisis, which is COVID-19. In a way, the pandemic combined the worst element of 1997 (large corporate debt) and 2008 (a contraction in the world's demand for Asian exports).

Empirical analysis - through vector auto regression models fit to data from the past three and a half decades - proves that, indeed, corporate debt is a significant source of financial 
stress in Asia. Jumps in the corporate debt-to-GDP ratio lead to higher volatility in the returns of banking, equity, bonds, and foreign-exchange markets. The response is either immediate (Japan and Singapore) or over 5 to 10 quarters (the PRC; Hong Kong, China; India; Indonesia; Japan; the ROK; Malaysia; Singapore; and Thailand). But the result is the same: less dollar-for-dollar capacity of those markets to intermediate savings.

Why would more corporate borrowing be a bad thing for financial stability? In general, a firm takes on loans to implement projects which, controlling for risk, should pay for themselves. But markets may have a different perception about how risky the project is. They would then price the stock of the firm and of its lender accordingly. This second effect seems to dominate in the Asian data. In other words, corporate transparency—or lack thereof - may be at play.

Has it always been like that? Things vary across the region. But a historical variance decomposition points out four distinct periods in the relationship between corporate debt and financial stress: pre-1997 (positive and strong, all economies in the sample), 1997 to 2008 (positive and weak, all economies), 2008 to 2018 (roughly neutral in most economies), and 2018 to today (positive in a few but major economies like the PRC; Indonesia; Japan; and Hong Kong, China).

Those past experiences carry lessons for Asia's policy response to the pandemic. The rush to inject financing into the corporate sector, welcome and necessary as it may be in the short term, is likely to cause financial volatility well into the medium term. The effect will be worse the more markets perceive that public funds go to companies whose commercial viability is in doubt - the "zombie firm" syndrome. Clear rules and transparent allocation of the public support are probably the best antidote.

\subsection{Household Debt: Supply-Driven Sugar Rushes}

Asia's public and corporate debts have been the focus of much analysis. Are they sustainable? And how do they affect macroeconomic performance? That focus is merited. But it is incomplete. Households have also been a major borrower in the region, but have received much less attention. Since the global financial crisis of 2008, they have taken massive amounts of debt, mostly to finance real estate. While households in the US and the euro area deleveraged, credit to households was growing much faster than the economy in the PRC; Hong Kong, China; the ROK; Malaysia; Singapore; and Thailand. By the time COVID-19 attacked, that credit ranged from 55 percent of GDP in the PRC and 95 percent in the ROK. That has brought risk onto the balance sheet of banks. And the pandemic, with its reduction in personal disposable income and its depreciation of illiquid assets, has turned that risk into a systemic threat.

In general, household indebtedness need not be a problem if it reflects investments that increase workers' productivity (like education does) or smooth their consumption (like mortgages do). But when it is large, of doubtful quality, or growing too fast, it can hurt economic growth and financial stability. Both effects may have been present in several Asian countries since 2010. To assess which effect is likely to prevail, a panel vector auto regression model was fit to the data of nine of the largest economies in Asia. ${ }^{6}$ The results are clear: a jump in household debt boosts economic growth in the short run but hurts it later. More specifically, an increase of 1 percentage point in the ratio of household debt to GDP causes a half-a-percentage-point expansion of the economy in the first year but a subsequent 
contraction of one and a half percentage points. The net effect is negative. This is consistent with previous findings in the literature for earlier periods in other parts of the world. But, in Asia, the economy's fluctuation due to spikes in borrowing by households is both larger (up and down) and shorter-lived.

A possible explanation for Asia's relatively less benign relationship between household debt and growth is the supply-driven nature of the borrowing, that is, banks pushing loans on individuals - perhaps as a result of laxer regulations. A telltale of that push would be a negative correlation between the part of household indebtedness that cannot be explained by growth and the "mortgage-sovereign spread" (the difference between the interest rates home buyers pay and the coupon in government bonds). The data confirm that the correlation in East and Southeast Asia (Hong Kong, China; Indonesia; Japan; the ROK; Singapore; and Thailand) is negative. In fact, it is more deeply negative than in advanced economies at large. The indications of loan peddling are strong.

This does not augur well. The pandemic represents a negative shock to growth, house prices, and mortgage-sovereign spreads. How households will react now will bear on the sustainability of their debt - and of the financial sector as a whole. Will default rates rise? Micro simulations using panel data from the PRC and the ROK, the two Asian countries whose citizens have borrowed the fastest over the past decade, let us explore the question. In recent years, observed defaults have been concentrated among the two lowest quintiles of both countries' income distributions. That is predictable, as the poor are expected to have more trouble making good on their debt. In fact, about 4 percent and 5 percent, respectively, of Chinese and Korean borrowers in the first quintile fail to pay back. An adverse shock ( 5 percent contraction in disposable income) would have raised those default rates by about 20 percent and 10 percent, also respectively. Note that a 5 percent fall in disposable income due to COVID-19 is well within the realm of the possible.

Asia's policy makers are well aware of the problem. For the past several years, they have been trying to manage the systemic risks behind household debts. Their macroprudential regulations target variables like loan-to-value, repayment-to-income, and debt-to-service ratios, especially in the financing of residential property. But none of those regulations kept household debt from growing fast. So new, even stronger restraints were being considered, among them broader collateral and appraisal requirements. The pandemic and the need to stimulate growth may have put a stop to those reforms. The time will come to resume them.

\subsection{Beyond Central Governments: Keeping Subnational Debt in Check}

Since the early 1990s, rapid fiscal decentralization has been the defining trend in public administrations around the world. The transfer to states, provinces, and municipalities of the power to decide over taxes and expenditures has proven popular. That was to be expected: for the average citizen, local authorities are easier to hold accountable than national officials when public services like education, roads, or sanitation fail. But decentralization also proved popular with financiers. They found new, eager clients for their loans. Some of that lending to "subnationals" made sense. But some of it ended in defaults and bailouts by the central government-whose own creditworthiness was at times compromised, as Argentina, Brazil, Mexico, or the Russian Federation can attest. So, a search started for an optimal system to 
regulate subnational borrowing. While progress has been made, the fundamental issue remains unresolved.

Asia is a prime example of the difficult dynamics between decentralization and debt - and of the attempts to put it on a sustainable path. The task is made even tougher by the region's unprecedented scale of urbanization and the associated demand for infrastructure. The World Bank has estimated that demand over the two decades through 2030 at about $\$ 16$ trillion. ADB puts the region's need to invest in infrastructure even higher, at $\$ 1.5$ trillion per year up to $2030 .^{7}$ The bulk of such spending will be the responsibility of local governments. How should they finance it, after a pandemic that has depressed their tax revenues?

One answer is to develop subnational bond markets. In that, four Asian countries present lessons that are particularly useful - the PRC, India, Indonesia, and the Philippines. The Chinese experience speaks of gradualism and phases. During the first phase, spanning from the early 1990s to the global financial crisis of 2008, the PRC's subnationals were not really allowed to tap markets. Instead, their funding came through loans from the central government, special-purpose vehicles, and land-based leases. These instruments were not liquid or transparent enough to be traded in a market.

The second phase (from 2009 to 2014) was about capacity building. Provinces set up debt offices, integrated them into their budget decisions and, in a few cases, piloted bond issuances with the central government as their agent. It was not until 2014 that the third phase started with the "New Budget Law". It allowed subnationals to issue bonds, within centrally determined limits that depended on creditworthiness. The bonds - some $\$ 3$ trillion-were used to repay and replace loans from banks and special-purpose vehicles, effectively securitizing the entire provincial debt. Today, only a small but growing portion of those securities have been traded. Still, the trading has helped differentiate provinces by creditworthiness, form a yield curve along longer and longer maturities, and expand the investor base-from commercial banks toward insurance companies, mutual funds, even foreign asset managers. All of these are slowly bringing market discipline to subnational finance.

In contrast to the PRC's gradual and recent approach, India has since its Constitution allowed its states to issue bonds, as long as they do it in local currency. But the states did not issue them. Instead, they preferred to have the central government borrow and onlend them the funds. Looking to impose market discipline on subnationals (and avoid political meddling from the center), the practice of central onlending was ended in the mid-2000s. This pushed states onto the bond market and to the closer scrutiny of banks, insurance companies, and other investors - although bondholders are reassured by clauses that guarantee the "intercept" of state treasury accounts. Municipalities did not follow their states, at least not yet or in the same dimension. Their financing through bonds is much more recent - it started around 2015 - and the full regulatory system was not set up until 2019. So, the jury is out as to how the market will evolve. So far, only about 2 percent of the country's 3700 "urban local bodies" have investment grade and are able to issue at reasonable cost.

Also under construction is the subnational debt market in Indonesia. While still small by international standards, the country's bond market grew apace over the past decade-it now stands at about 20 percent of GDP. But all the expansion was in sovereign and corporate bonds, in part due to a policy effort to reduce the economy's exposure to foreign currency. Subnationals have not tapped the market; regulatory requirements for their bond issuances were relaxed only in 2020 . 
Similarly, no subnational bond market has developed in the Philippines. Partly, this is because the "local government units" are not responsible for major expenditures - notably, they are not responsible for infrastructure. Partly, this is due to strict regulatory restrictions, like low ceilings on debt-service ratios. And partly, it is the result of the supremacy of public banks, which have the capacity to intercept municipal revenues. Total subnational debt is estimated at less than 1 percent of GDP, and is almost entirely owed to public banks. A guarantee corporation to spur lending from private investors was closed in 2019, for lack of use.

In all four cases, the systems to regulate borrowing by subnationals played a critical role in the development or not of their bond markets - rightly so. At its core, the regulation is about preventing the problem of the "common pool", that is, states or municipalities taking on more debt than they can repay, thinking that the central government will be forced to bail them out with the money that belongs to the country as a whole. The incentive works for financiers too: if bailouts are to be expected, there is little risk in lending to borrowers that are not creditworthy.

The PRC tried to regulate the problem away by centrally imposing a limit on the size of each province's outstanding debt, including guarantees, as well as laying out detailed procedures and control for issuances. These are accompanied by an early warning system and annual assessments, both managed by the central ministry of finance. India tried to tackle the common-pool issue through federal- and state-level fiscal responsibility laws. These put ceilings over variables like fiscal deficits and debt stocks. With much less-developed subnational debt markets, Indonesia and the Philippines have deployed their financial services authorities and even their central bank to keep subnational borrowing in check.

But, controlling indebtedness is in a way equivalent to controlling the symptoms. How does one control the causes of subnational debt so that it stays sustainable? The answer is in a consistent balance between the intergovernmental fiscal system, the mechanism to manage debt distress, and the transparency of contingent liabilities. The first sets out the revenue sources and expenditure responsibilities of subnationals. What can they tax? What do they have to pay for? What transfers will they get from the central government? The second tells lenders what to expect if a state or municipality cannot pay them back, so they can price and ration their credit accordingly. And the third makes sure that states and municipalities do not hide or delay their true spending by making promises they cannot pay-whether to suppliers, developers, or pensioners. On the three fronts, the systems of Asia's largest emerging economies are still in the making.

\section{THE RISKS BEHIND ASIA'S DEBT}

Heeding the lessons from the Asian financial crisis of the late 1990s, the region's policy makers have done much to ensure that private debt does not become systemically destabilizing again. Law, regulations, and practices have brought more discipline to the borrowing done by corporations, households, and even subnationals - and to the lenders that make funds available to them. With one exception: the same kind of discipline has, in the main, not applied to public debt. The one exception is the gradual shift in composition, from foreign to local currency. But borrowing by Asia's central governments remains volatile, a reflection that their fiscal accounts remain volatile too. Part II starts by studying that volatility, in itself and through the 
lens of fiscal space. It then looks at the three latent risks behind most of the region's fiscal frameworks: contingent liabilities, subsidies, and aging.

\subsection{Fiscal Uncertainty: The Thankless Task of Forecasting Asia's Fiscal Accounts}

The terms and price of public debt depend on the projected path of the fiscal accounts. But what if that path were volatile? Markets would then demand a premium to hold sovereign bonds. In practice, they do, for fiscal outcomes are extremely difficult to predict. Government budgets rarely pan out. The evidence of this is overwhelming. But there are major differences in the volume and sources of uncertainty when comparing advanced and developing countries. The dichotomy is true across regions, including Asia.

Define fiscal risk as the possibility of large or systematic deviations of fiscal outcomes from their expected values. Focus on forecasts one and two years ahead for variables like the ratio of public debt to GDP and the overall budget balance. And use projections and outcomes published by the IMF - arguably the best global source of fiscal predictions - in, roughly, the decade and a half up to 2019. The results are eye-opening: across all countries, one-year-ahead forecasts missed debt ratios and budget balances, on average, by 1.5 and 0.6 percentage points of GDP, respectively. Two-year-ahead errors are, as one would expect, larger: 2.4 and 1, respectively.

But a better sense of the problems associated with fiscal forecasting comes from the "interquartile range" in the distribution of errors in prediction across countries. Think of it as the difference between the lowest level of error for the most pessimistic quarter of countries, and the lowest level of error for the most optimistic one. That difference is 8 percent of GDP for debt and 3 percent for budget balances in one-year-ahead projections-much worse in two years.

Those are big margins if you have to assess the creditworthiness of a government or if you have to program its monetary policy. They are also heavily skewed-underestimates of debt and deficits are much more common than the opposite. Optimism prevails.

There are, however, important differences across types of countries. Forecasting errors in advanced economies are much smaller than in emerging and developing ones. For the former, the gap measured in percentage of GDP between one-year predictions for debt and deficit ratios and the actual values are 0.3 and 0.3 ; for the latter, they are 2 and 0.7 . Asia, with its mix of rich and not-so-rich economies, does not escape the fiscal volatility. In East Asia (minus Japan and Singapore), next-year debt ratios and fiscal balances are on average underestimated by 0.5 and 0.7 , respectively, while in South Asia they are overestimated by 1.2 and 0.3 .

The causes of the errors also vary across national income levels. For advanced countries, having the wrong prediction for economic growth explains a relatively large share of the miss (40 percent of their variance). For the rest of the world, it only explains a tenth: country-specific factors, like commodity dependency, disasters triggered by natural hazards, and institutional quality matter much more. So do the stability of their currencies - devaluations are hard on projections when a significant portion of public debt is denominated in foreign currency. Estimates show that a 10 percent depreciation is associated with a 2.5 percentage point unexpected increase in the debt-to-GDP ratio. But, for all types of countries and in all regions, the main source of errors remains unknown: the so-called "stock-flow reconciliations", that is, the unexplained part of the debt accounts for about half of all errors. 
The behavior of forecasting errors over the economic cycle also differs by income level. In emerging and developing countries, those errors are more pronounced in bad times, even if bad times were anticipated. But downturns make no difference to the precision (or lack thereof) of forecasts in advanced economies. Their capacity to implement countercyclical fiscal policy may be behind that.

This analysis raises the question: are Asian countries — as represented by ADB's regional members - fiscally riskier than their peers in other regions? No, as a group, they are not. But their average forecast error is still quite large-1 percent of GDP for budget balances. So is the variance among them, with small island states, commodity-dependent countries, and those with large foreign-currency debt burdens being, by far, the toughest to predict. Places like Azerbaijan, the Kyrgyz Republic, Kazakhstan, Maldives, and Tuvalu have over the past decade been outliers, both for vastly underperforming their fiscal plans in some years and overperforming them in others. And in a delightful illustration of the underlying uncertainty, for the average ADB borrower forecasts are more precise two years out than one.

The overall message is clear: fiscal frameworks are difficult to predict. Governments, even capable ones, pay a price for that. Their credit ratings are lower and their cost of borrowing is higher than they would be in a world of perfect foresight. So, forecasting capacity as well as policies and financial instruments that reduce the uncertainty ought to be a priority, in Asia and elsewhere.

\subsection{Fiscal Space: Asia's Fiscal Safety Net has Shrunk}

Economies can be knocked off balance by temporary retrenchments in private consumption or private investment, or by major disasters triggered by natural hazards. At those times, governments are expected to hike expenditures or cut taxes in order to stabilize output or to kick-start reconstruction. This is critical to maintain their own creditworthiness, for public debt is perceived as riskier during downturns and catastrophes. But not all governments have the capacity to spend more or tax less without putting macro-financial stability at risk, that is, not all have "fiscal space". Those who are already running deep deficits or who have limited access to market financing at reasonable cost could hardly afford more borrowing. In other words, fiscal space is to debt sustainability what seatbelts are to car safety.

Do Asia's developing countries have fiscal space? And how has it been affected by their response to the pandemic - an event that combined both an aggregate demand contraction and a natural disaster? Looking at a group of 38 governments, the answer is mixed at best. ${ }^{8}$ While better than other developing countries, the fiscal stance of developing Asia was not strong when COVID-19 arrived. As proportions of GDP, the median public debt and fiscal deficit in that subset of the region were 41 percent and 1.8 percent, respectively. Not too bad by international standards, and better than emerging and developing economies elsewhere (53 percent and 2.5 percent).

However, a more sobering view comes from looking at the fiscal sustainability gap - the difference between the actual fiscal balance and the balance required to stabilize the public debt burden. By this measure, those Asian economies had a median, positive fiscal space of 0.7 percent of GDP at the end of 2019, while their peers in the rest of the world had a negative 1.3 percent. But that median fiscal space in Asia was a lot smaller than what it was right 
before the global financial crisis of 2008, when it stood at a positive 5.4 percent of GDP. The deterioration was fast.

COVID-19 trounced whatever little fiscal space Asia had. All countries in the region suffered a collapse in growth and all responded with fiscal stimulus. Judging by IMF projections right before and right after the declaration of the pandemic, developing Asia suffered an average loss in output of 7.4 percent and an average deterioration in fiscal deficits worth 5.4 percent of GDP. That is, while slightly smaller than in the rest of the world, those were huge blows to economic and financial stability. The responses took many forms - from more cash transfers to individuals and tax relief for corporations to guarantees for bank lending and employment protection schemes. By all accounts, this must have consumed most, if not all, remaining fiscal space, at a time when bond spreads spiked and private external financing became much dearer.

The overall, steady decline in fiscal space before the pandemic, and its steep fall after, will be costly for Asia in the long run. While too early to tell, indications are that, to make ends meet, public investment in infrastructure has become those governments' adjustment variable. Available data for 24 of them indicate that 15 trimmed their capital outlays in 2020 . The median trimming was about 0.2 percent of GDP, moderate compared with other developing countries ( 0.6 percent). In some, it was much more drastic than that-Cambodia, Sri Lanka, Tajikistan, and Viet Nam. Projects were postponed or delayed, not unlike what happened after the global financial crisis of 2008. If so, it would be a pity, for it would hamper the recovery and it would delay development.

How could developing Asian economies create more fiscal space? First, structural reforms, especially doing away with distortive and regressive subsidies-notably to fossil fuels. Second, debt relief. This goes beyond debt service suspension, as the funding need is for projects, not liquidity. Third, precisely because projects are involved, participation by the private sector should be a priority. Multilateral development banks can then play the role of mobilizing private investors, whether by financial risk mitigation or by socialization of country and sector information. And fourth, for those countries who have not done it, launching now the long process of growing the domestic capital markets, both as a means to raise the level of national savings and to channel them. This would match well an aspect of public investment that experience tells us is highly desirable in economies with limited institutional and implementation capacity: gradualism.

\subsection{Contingent Liabilities: Controlling Exposures that are Difficult to Measure}

It is common practice for governments to accept payment obligations that depend on whether a specific event takes place. A private contractor is invited to fund a toll road and is promised compensation by the public treasury if traffic falls below an agreed volume. A bank is given a public guarantee so it extends a loan to a state-owned enterprise. Retirees are told to expect a minimum pension, even if their savings do not generate enough return. A city may be just too large and too politically important for federal leaders to let it go bankrupt. These "contingent liabilities" are not quite debt - the underlying promises may never be called on. But if they are, they can throw fiscal plans off track. They are a major risk to debt sustainability. When they are publicly known, credit ratings will reflect them. But they are not always known, reported or even documented. 
The world is strewn with stories of contingent liabilities gone bad, dating back at least to the nineteenth century. The calls for payment usually came as a "surprise", were costly (several percentage points of GDP), and caused major macroeconomic turbulence. Asia has not been spared — witness the bank bailouts during the 1997 crisis.

How big are Asia's contingent liabilities? Nobody knows for sure. The databases that exist differ widely in definitions, timing, coverage, and valuation methods. Debt can be defined in a traditional way (bonds and loans), as non-equity liabilities (to include things like account payables), or as only debt instruments (which would leave out options). And for a given definition, debt can be valued at face value, market value, or amortized cost.

One way to reach an estimate of possible contingent liabilities is just to assume that the central government is responsible — explicitly by contract or implicitly by practice - for all the debts of certain kinds of entities - provinces, municipalities, state-owned enterprises, publicprivate joint ventures, and so on. This relatively simple technique provides an upper-limit for exposure. Applying it to Asia's five largest economies is telling, both for what it can and cannot reveal. Take, for example, contingent liabilities arising from subnational governments. They amount to 24 percent and 39 percent of GDP in India and Japan, but to only 0.3 percent and 2.4 percent in Indonesia and the ROK. The calculation for the PRC is trickier, at least using global databases. Best estimate is about 40 percent of GDP.

The same method can be applied to the other major source of government contingent liabilities: nonfinancial public corporations. Estimates for that debt range widely, from about a tenth of GDP in Indonesia to more than half in the PRC. (The PRC's figure can exceed 100 percent of GDP, depending on whether special-purpose vehicles are considered debt of municipalities or of public corporations.) How about financial public corporations? The calculation is much less reliable because public banks lend to the central government. Without netting out those loans, the count can be enormous - it tops almost 200 percent of GDP in Japan and about 70 percent in India and the ROK. No global database carries this information for the PRC.

Clearly, a government's liability exposure to public entities - subnational governments or public corporations - is difficult to assess. This assessment is even more difficult for exposures to private parties. Two of those parties stand out: private-public partnerships for infrastructure, and commercial banks. They usually obtain - formally or informally - government guarantees that projects will be profitable or loans will be repaid. The probability of that happening is at best uncertain and at worst unknown. So, a conservative way to calculate the size of the contingent liability in infrastructure partnerships is to assume that the government may be called upon to return the entire private investment. By that measure, Asian exposure is relatively small-less than 5 percent of GDP in the PRC, India, and Indonesia. That may or may not be the case with commercial banks, for data on public loan guarantees or on the quality of the projects the loans fund are effectively missing - and not only in Asia. An indirect, order-of-magnitude proxy is to look at the total liabilities of banks, assume that they are all covered by deposit insurance, and that the public treasury might be called to make good on them. By that very imperfect measure, the contingency in Asia would range from about half (India) to over 100 percent of GDP (the ROK).

Fortunately, problems in calculating the exact size of contingent liabilities have not prevented policy makers in Asia from trying to control them. Assuming that the liabilities are large and potentially destabilizing - probably the right assumption - they have looked for ways to control them, mostly through measurement and reporting. Countries like Bhutan, 
Fiji, India, the Philippines, and Thailand disclose in their financial statements the outstanding amounts of government-guaranteed debt. This becomes part of their sovereign credit rating, putting a subtle but binding limit to how big that debt can be. Others not only report their guarantees, but also put a legal ceiling to their stock (Armenia) or flow (India). This is a welcome practice. The question remains, though, whether what counts is the value of the promise if called or that value should be adjusted down by the probability of the call (as the US does). The former is more restrictive.

But guarantees are a relatively small portion of all the contingent liabilities that governments face. So, another approach that has gained some momentum in Asia is to enlarge the perimeter of what "government" is, and include subnational entities, agencies, or public corporations. This defines a "general government", and turns into public debt what would otherwise be contingent liabilities. This approach, pioneered by Australia, the European Union, New Zealand, and the United Kingdom, has also been adopted by Myanmar and Thailand. ${ }^{9}$

Whatever the tool for control (disclosure, caps, perimeters, or their combinations), the time for action is now. As part of their response to the pandemic, Asian governments have included contingent liabilities - many in the form of guarantees - in their stimulus packages (e.g., Japan and the ROK). The longer COVID-19 and its effects linger on, the more likely those liabilities will be realized.

\subsection{Debt Generators: The Case of Electricity Subsidies}

The accumulation of public debt—and its sustainability afterward — is driven by fiscal deficits. Simply put, government expenditures outstripping government revenues. Money being fungible, it is impossible to blame the need to borrow on a single outlay (for being too big) or intake (for being too small). But, sometimes, there is an expense in the public accounts that is so large, so regressive, and so inefficient that it is difficult to overlook. Price subsidies for electricity is one of them. In Asia, two countries best exemplify the problem and the lessons that others could heed. They are Pakistan and Sri Lanka.

There are four ways in which subsidizing electricity, or energy in general, adds to fiscal deficits. First, when suppliers are forced to sell electricity below cost, and then call on the government to fund the losses. Second, by slowing down growth; with prices below cost, there is no space or incentive to invest in more supply. Third, by giving up the opportunity to export it at world price. And, fourth, by spreading government guarantees in favor of power companies - usually compromising the domestic banking sector.

Those four channels of transmission have, at various times and with varying intensity, been present in both Pakistan and Sri Lanka. Interestingly, the subsidies recorded in their fiscal accounts (the first channel) are meaningful but do not seem exorbitant: 2.3 percent and 0.5 percent of GDP, respectively, per year on average over the past two decades. That is on a par with Bangladesh (2.6 percent), India (1.3 percent), Indonesia (2.5 percent), or Viet Nam (1.1 percent). But the impact on debt accumulation has anyway been huge. How come?

The reason has to do with the method of estimation. Rather than count cash losses, it is better to ask the question: how much lower would the public debt burden be if, during those two decades, the countries had practiced a subsidy-free electricity policy? The answer requires modeling and assumptions on growth, fiscal policy, and capitalization of state-owned power companies. Even under very conservative assumptions, the difference is dramatic for Pakistan: 
its public debt, which today stands at about 80 percent of GDP, would be 25 percentage points of GDP lower. That is a much healthier and more sustainable financial position to be in. For Sri Lanka, whose public debt also hovers at around 80 percent, the effect is smaller but still significant: 10 percentage points of GDP. This reflects its much less-generous subsidy policies. And for both countries, the foreign-currency-denominated portion of public debt would have fallen by more (Pakistan) or increase by less (Sri Lanka) than it actually did.

Notice that those calculations do not take into account the entire balance sheet of the state, just its liabilities. Providing below-cost electricity discourages conservation. Pollution and other environmental damage coming from the excess consumption depreciate the country's assets more than would otherwise be necessary. This makes the increase in net indebtedness greater than what our model predicts.

Still, there may be reasons to subsidize electricity, even if that weakens public finances. The most commonly cited has to do with giving access to all citizens as a right, sometimes independently of their willingness or ability to pay. If so, selling below cost may not always work: access in heavily subsidized Pakistan has barely moved in the last 20 years (and remains at about 70 percent of the population), while in much less-subsidized Sri Lanka it has reached almost 100 percent. A similar observation can be made about the effect of electricity subsidies on labor force participation of women-Pakistan has been outperformed by Sri Lanka. Note that these outcomes happened even though both economies were growing fast ( 4.4 percent and 5.2 percent per year, respectively, on average during 2000-2019).

Why have countries in Asia and elsewhere not dismantled electricity subsidies? Because it is politically costly. It involves raising tariffs to consumers for a service that is currently of bad quality. Several countries in the region have tried, at least, to target the subsidies on the poor (India, Indonesia, and Malaysia). Others outside the developing Asia group, like Iran, have tried compensatory schemes, effectively returning to citizens a portion of the fiscal savings. But overall progress has been slow. Ironically, COVID-19 might bring a new impetus to this agenda: the pandemic will leave behind bloated fiscal deficits, massive debt burdens and, likely, a long path to full recovery. Governments will be looking for ways to balance their books. Cutting price subsidies to electricity seems like the obvious first place to look.

\subsection{Aging: The Demographic Elephant in the Fiscal Room}

Asia's richer economies are aging fast. The change is not just demographic - it is also economic. The effective labor force is shrinking, partly due to more schooling and later entry into employment. And the old-age gap, that is, the difference between consumption and labor income for those 65 and older as a percentage of the salary of an average worker, is widening. Two decades from now, the PRC; Japan; the ROK; Taipei,China; and Thailand will look like Europe does today (and a far cry from Bangladesh, India, Indonesia, Pakistan, and the Philippines). A couple of observations are quite telling: the PRC's effective labor supply is already falling by an estimated 0.7 percent per year, and Japan's old-age gap is the largest in the world. For them, the era of growth fueled by population has long ended.

Will this make their debts more or less sustainable? Difficult to say in the abstract. More older people relatively to the young means more fiscal expenditures relative to tax revenuethe new old need health care and pensions, while there are fewer young to work and pay taxes. This means a larger "supply" of public debt. But the greater cohort of individuals growing in 
age may "demand" more of that debt as a vehicle to hold part of their savings for retirement. The net outcome becomes an empirical matter.

So, to evaluate the effect that aging will have on the sustainability of Asia's debt, country-specific and regional projections - and assumptions - are required. It is also necessary to estimate "National Transfer Accounts", that is, how much each age group pays in taxes and gets in government-funded age-related benefits.

The results show that, because of aging, the "supply" of total debt in Asia will triple over the next 40 years. It will more than double as a proportion of labor income, with the increase front-loaded in the coming two decades. The lion's share-about three-quarters-will remain concentrated in East and Southeast Asia. And some 40 percent of it will be public. In fact, by 2060, public debt in the PRC; Japan; the ROK; Singapore; and Taipei,China will be equivalent to 400 percent of GDP or (much) more. It will be over 600 percent, 900 percent, and 1,500 percent of GDP in the PRC, the ROK, and Japan, respectively. And its buildup will start soon: by 2040 , it will have already reached 200 percent of GDP in the PRC, the ROK and Singapore, and over 600 percent in Japan.

Those numbers are multiples higher than the amount of public debt that savers will be willing and able to hold - on average for East Asia, some 150 percent of GDP by 2060 . Even if those savers were to shun all private debt in favor of a public one, it would not be enough. What to do? Everything else equal, and short of a major rejuvenation through migration, the net benefit package that governments offer will need reform. In the long run, aging will make the current financial status quo unsustainable.

But everything does not need to stay equal. Technology may still save the day. A major breakthrough, say, in artificial intelligence or robotics could raise productivity well above the 1.5 percent per year assumed in our projections. That would deliver faster growth and help balance the books. But new technologies, say in genetics, could also raise life expectancy and drive the fiscal accounts deeper into the red, making public debt less sustainable sooner. So, the uncertainty works both ways. A much safer way is to start reforming tax and social security systems now, making net benefits more compatible with what can be realistically afforded.

\section{WHAT NEXT? POLICIES TO KEEP ASIA'S DEBT SUSTAINABLE}

As mentioned earlier, Asia's policy makers learned from the crisis of 1997. They put more discipline over private borrowing and over bank lending. They inserted more transparency in corporate finance - albeit not nearly enough. They kept a tight(er) leash on subnational debt. And, more fundamentally, they developed their domestic capital markets, which became the main and marginal source of fiscal financing. Not all countries progressed equally far or in all fronts - some still face the basic task of strengthening their public debt management capacity. But the direction is clear.

So, how to build on that progress? Two priorities. The first one is to bring debt management capacity up to standard where it is lacking. This is urgent, as financial conditions will tighten in the fiscal reckoning that will likely follow the pandemic. The second is to seek new financing instruments, for diversification of sources and for hedging of risk. Both priorities are discussed below. 


\subsection{Debt Management Capacity: A Tale of Three Asias}

The Asian financial crisis of 1997 was not about government debt—it was about banks making bad loans in the wrong currency. But it highlighted the need to develop the region's domestic bond markets. The task naturally fell on public debt management offices - they were after all the largest domestic issuer. Two decades on, they delivered. In most countries, those offices' technical capacity was enlarged and enhanced. This could not have come at a better time: the volume of public and publicly guaranteed debt has since then risen fast, and has ballooned through the pandemic. What needs to be done now both to preserve Asia's sound track record in public debt management and to navigate the new reality?

The answer calls for some categorization, as the region varies widely from a debt management perspective. Three distinctive groups of countries can be identified. First, those whose governments are primarily or exclusively financed by foreign official creditors and donors, with little domestic debt, and almost absent domestic bond markets. This includes most of the Pacific Island economies and other developing Asian economies such as Bhutan and Cambodia. For their public debt managers, the job remains one of selecting, recording, auditing, and reporting the best possible loans from their official lenders. But some may soon be facing a new assignment: negotiating the restructuring of their debts. Do they have the capacity? The evidence is patchy, and it comes mostly from assessments by the World Bank and regional auditing associations. While it points to recent progress, it also points to a need for support over the next couple of years.

At the other end is a second group of Asian countries whose public debt is entirely financed domestically - their capital markets are large, liquid, and deep. These are the likes of the PRC, India, Malaysia, Singapore, and Thailand. For them, the short-term priority is to manage refinancing and interest-rate risk. This, in turn, means monitoring and nurturing their domestic securities markets, where they can borrow with long tenors in local currency. Their technical capacity to do that is, in most cases, world-class.

Finally, there is the third and largest group of governments who fund themselves with a wide-ranging mix of official sources, domestic markets, and international capital markets. This is the practice in Armenia, Georgia, Indonesia, Pakistan, and the Philippines, among 24 others. Since they must be able to tap and trade off any of those markets at any time, their capacity is always stretched. By the information available, most of them have coped well. Issues of coordination and transparency remain, though - to be expected when several agencies are involved. The real test of their abilities will come soon, as many of their governments built up large debts during the COVID-19 crisis.

For all groups, the pandemic has jolted their strategies and stressed their operational systems. From changing the assumptions behind their annual borrowing plans to having their staff working from home, public debt offices have been put to the test-and the test is still unfolding. But what will happen after the dust settles? On which areas will Asian public debt managers have to focus? Five stand out. First, transparency. This is not an area where the region shines. Disclosing objectives, communicating regulations, and publishing debt stocks, composition and expected trends are crucial to keep markets stable. This will also help build better relationships with investors.

Second, fiscal risk. This involves exposures to contingent liabilities, disasters triggered by natural hazards, and commodity price volatility. They are rife across Asia. They weaken fiscal 
frameworks and make financing more expensive. Responsibility over them is spread across government agencies, which makes the work of public debt offices all the more difficult. New tools exist to address the problem-like buying insurance against earthquakes or commodity price swings. But they are not common, partly because the necessary institutional capacity is yet to be developed.

Third, sovereign asset and liability management. Neither firms nor individuals make decisions about their debts without taking into account their assets. Governments, regrettably, do. And Asian governments are no exception. There are good reasons for that - calculating a complete balance sheet of the state is no easy task. But, at least for financial assets, it is possible. This would allow a better match of currencies, interest rates, liquidity, and cash flows coming from assets and liabilities. It would also improve the country's credit rating. The problem is mainly one of coordination among central banks (who hold reserves), sovereign wealth funds (bonds and stocks), ministries of finance (taxation), and state-owned enterprises (dividends). But, as Indonesia has shown, it is not an unsurmountable problem.

Fourth, thematic bonds. Over 3,000 of the world's largest asset managers have signed up to the United Nations-sponsored Principles of Responsible Investment. That means that they are committed to allocating a growing part of their portfolio to be consistent with and foster a public agenda of environmental protection, social progress, and good governance (ESG). At last count, that portfolio is worth some $\$ 100$ trillion. Not surprisingly, a growing number of borrowers - public and private - are issuing bonds with the promise to use the proceeds for ESG purposes. They do not get better financial conditions for the promise. But they expand their funding sources. By now, many corporations in Asia, as well as a growing number of governments, have tapped this market—with "green", "blue", "gender", and "Islamic" bonds. This takes skills that not all public debt offices currently have.

Last, there is the long-haul task of building domestic capital markets. This is pending or just-started in the less-developed parts of Asia-13 of those countries have no domestic market at all. As explained earlier, the necessary building blocks are known and there is room for cross-country learning across public debt offices. The rewards will be big, as the region has high national saving rates, large infrastructure needs, and a healthy apprehension to borrowing in foreign currencies.

\subsection{Fiscal Insurance: A New Tool of Fiscal Stability}

A government's debt is as sustainable as its accounts. The cost of borrowing for the public sector - and the market price of sovereign bonds - hinges not only on the size but also on the stability of fiscal revenues and expenditures. The risk of, say, a natural disaster or the wrong turn in commodity prices is factored in credit ratings and spreads. That is why volatile deficits are more expensive to finance than stable ones. So, ministers of finance have an incentive to hedge risks. In advanced economies, they do. Countries like Australia, France, Japan, Spain, the US, and the United Kingdom have found ways to insure themselves, or the people and sectors they would otherwise have to help when shocks happen.

But why, in spite of recent successful experiences, is fiscal insurance not more common among emerging economies and developing countries? They, after all, have less financial capacity to deal with shocks. Their first response is usually to borrow more at higher cost. And, if that is not enough, they shift resources within their budgets toward the short-term emergency 
and away from long-term projects - the adjustment variable is public investment. Either way, they end up with a heavier debt burden, less development, and more poverty. This is a bad position to be in, as global trends like climate change are making shocks more frequent and more severe.

In the developing world, only one country has made it a practice to buy insurance against its main fiscal risk. That country is Mexico which, since the early 1990s, has been hedging its oil income by purchasing put options - a smart move, for oil-related income has on average represented a third of its fiscal revenues. The cost has not been small, about 0.1 percent of GDP per year. But, when the options were exercised, the benefits were not small either - some 0.4 percent of GDP each time. The Mexican government has also built a sound system of fiscal insurance against disasters triggered by natural hazards, based primarily on the sale of catastrophe bonds, that is, debt whose proceeds are only accessed by the issuer, and do not have to be paid back, if a predefined crisis strikes.

For all its merits, the Mexican example was not followed until very recently and only by a limited number of countries. Their experiences have been equally positive and carry major lessons for the expansion of fiscal insurance. Take the case of the Philippines. It is extremely vulnerable to typhoons and earthquakes - just a single event in 2013 cost almost 5 percent of GDP in losses. Starting in 2016, the central and 25 provincial governments bought an insurance policy against typhoons. The policy was "parametric" (as opposed to "indemnity"); it was designed to pay out a fixed amount (not an indemnification for actual damages) if a disaster meeting certain parameters-like a storm's speed or location - happened. The following year typhoon Vinta met those parameters, and the payout to the affected province (Davao del Sur) was four times the premium it had paid for the coverage. This created public support to expand and renew the policy to this day.

Other countries used a similar formula. Uruguay protected its fiscal accounts against droughts and spikes in oil prices. Since the vast majority of its electricity comes from hydropower, when rains fail it is forced to buy fuel abroad. Unable to pass the higher cost to consumers, the credit rating of the government was linked to the weather-perhaps the worst kind of risk. It has, since 2013, broken that link by buying insurance. Morocco (butane gas) and Tunisia (oil) have done the same. Several small island states in the Pacific (earthquakes, cyclones, tsunamis) have joined forces to pool risks and buy coverage together. So have 16 countries in the Caribbean (hurricanes).

But what made all these transactions possible? What was the innovation? In a nutshell, the fact that governments could buy the policy - whether in the form of a contract or a catastrophe bond-from a multilateral development bank (mostly the World Bank). The bank, in turn, sold a mirror policy to international investors, carrying no risk on its own balance sheet. The intermediation has helped overcome the two obstacles that had all but frozen this market. The first is on the demand side: governments are politically reluctant to buy insurance directly from a private financier, lest they be accused of corruptly "paying for nothing". For them, it is politically easier to buy it from a developmental institution of which they are shareholders. Being nonprofit, those institutions pass the insurance at cost, for a nominal fee, effectively sharing their procurement capacity, their creditworthiness, and their market relationships (their "Rolodex") with the country. This is no different from what development banks do with their loans except that, with insurance, the size of their capital is not a constraint. Moreover, as part of their mandate those banks are happy to form local capacity and share best practices. They 
are also able to mobilize the best scientific expertise — defining and monitoring the parameters of an earthquake is no simple task.

The second obstacle is on the supply side: global investment houses are unwilling to engage in this type of operation with governments that may lack technical capacity, offer unclear legal and judicial frameworks, or have not previously signed master agreements that meet the standards of the International Swaps and Derivatives Association-that is, most developing countries. For them, the counterparty risk is too large when compared with a multilateral bank. A hint of that perception is in the fact that all intermediated transactions have been oversubscribed - in other words, private investors were crowded in.

The wedge between demand and supply points to the path forward. The scaling up of fiscal insurance may require a dedicated international agency. Isolated transactions carried out by multilateral banks as part of their existing mandates and staff envelopes may not sufficebeyond the initial demonstration effects. Instead, a new institution, focused on becoming the world's market maker for fiscal-risk instruments, may be called for. It could provide a one-stop, trade execution platform, from contracting geological experts to running offer books. It could distill and disseminate experiences and knowledge. It could offer capacity building. It could help countries articulate legal frameworks for risk management products. And it could become a source of transparency and standardization of documents. Put differently, the world has several international institutions that were created to protect investors, like the Multilateral Investment Guarantee Agency. It may be high time to create one that protects governments.

\subsection{Thematic Bonds: A New Tool for Diversification of Fiscal Financing Sources}

Suppose you are an investor looking to buy a bond. If you could choose between two bonds that are identical except for the fact that one credibly promises to use the proceeds for a good cause and the other one does not, which one would you choose? The answer is obvious. And it is the genesis of "thematic bonds"- securities in which the issuer commits to spending the funding on a certain "theme" or purpose. The idea was first pioneered by the World Bank back in 2006. At that time, the commitment was to use the funds to vaccinate 500 million children in 10 years. The "vaccine" bonds were thus born. They were so successful that, two years later, the same bank issued the first "green" bond to pay for climate-related projects.

Fast forward to today. Hundreds of private corporations and dozens of governments and multilaterals have issued thematic bonds-blue, gender, governance, green, Islamic, and social. The growth has been exponential, with over $\$ 300$ billion in issuances in 2019 alone. What gave momentum to the trend was the launching of the United Nations-sponsored "Principles of Responsible Investment" in 2006, calling for investors to keep ESG concerns in mind when buying and managing their investments. As mentioned earlier, more than 3,000 global asset managers have signed to those principles. They control a portfolio estimated at $\$ 100$ trillion dollars - about half the size of the world's capital market. They represent a giant opportunity for public debt offices to diversify their sources of finance, something that was valuable before the pandemic and will become priceless after it.

And yet, so far the vast majority of thematic bonds have been issued by private borrowerscommercial banks and corporations - multilateral institutions, and state-owned enterprises. Governments themselves, including in Asia, have been less enthusiastic. The first to tap this market was Poland (2017). By the end of 2020, 18 others had followed, four of which are from 
Asia (Fiji; Indonesia; Hong Kong, China; and Thailand). What needs to change for more of them to adopt this type of financing?

The answer is in the incentives. Thematic bonds are not "cheaper" for the issuer, meaning, they do not necessarily command a better price, lower coupon, or longer maturity than plain bonds. This is because their credit rating still depends on ability to repay, not on how the proceeds are used. There are also extra costs, in time and money, associated with interministerial coordination, project identification, certification, monitoring, reporting, and evaluation. And, like in any new market, there are operational uncertainties. The "green" or "social" labeling of a bond is usually based on broad, voluntary guidelines from the International Capital Markets Association, but universally accepted standards do not exist. The Association of Southeast Asian Nations Capital Markets Forum, which brings together regulators from 10 Southeast Asian countries, launched its own green, social, and sustainability standards starting in 2017. And stock exchanges - London and Luxembourg — have put forward their own requirements for listing thematic bonds.

Similarly, there is no industry standard for the providers of external reviews (whether opinions, verifications, certification, or scorings) for the eligibility or impact of the projects that the bonds fund. The nature of those providers ranges widely, from nonprofit research institutions to global credit-rating agencies. With that much discretion still at play, it is not surprising to see no record of legal action against an issuer for defaulting on the promise of a thematic bond, as opposed to defaulting on its repayment.

But, beyond those teething problems, there are benefits. The first is the diversification of financing sources mentioned earlier. The second is reputational, especially for governments that are already committed to a certain cause (say, environmental protection) and want to signal that commitment. For example, France issued its first sovereign green bond in January 2017, after the signing of the Paris Climate Agreement. The third benefit is about budget stability for line ministries - the projects promised by the bonds are unlikely to see their funding cut during a fiscal crunch. And the fourth has to do with stability. There is evidence that buyers of thematic bonds tend to be buy-and-hold investors. This results in less price volatility, more long-term relationships, and easier rollovers.

Public debt managers are right to ponder those pros and cons. But time may be running short for them to decide their strategies. The community of buyers of thematic bonds is expanding fast and now includes central banks, corporations, foundations, and religious organizations, all looking for investments that can generate social or environmental impact alongside financial return. In the not-so-distant future, no asset manager may want to be on a "negative list" of those who do not care for or cater to ESG principles. Showing how funds are spent may then become a practice in most bond issuances. A 2020 survey by the World Bank asked those public debt managers what kind of questions they get from their investors. By far the most common inquiry is about their governments' plans to issue thematic bonds - 80 percent of prospective buyers ask about it.

\section{CONCLUSION}

Whether cut by public or private, foreign or domestic, in advanced or in developing economies, Asia's debt seems large — in some cases extraordinarily so-but sustainable. Yes, the pandemic has worsened the burden-more borrowing, less GDP. Yes, poorer, isolated and 
aid-dependent countries need help and need it soon. And, yes, shrinking fiscal space, contingent liabilities, and sticky subsidies are real and present dangers. But one gets a sense that this is not a debt problem that could not be solved by a return of economic growth to its past mean and a doable dose of fiscal consolidation. There is no sense of imminent explosion. The key word is "imminent", as the irreversible and accelerating pace of aging will make public debt in East Asia impossible to carry in a couple of decades from now.

This leaves the region's policy makers with a mix of praise and homework. They deserve credit for their laser focus on growth, for creating enough confidence in their national currencies, and for developing their domestic capital markets. All that, which they learned from past crises, made debt much easier to carry. But their work is far from done. Reforms are needed to balance fiscal accounts in the medium term and make them more stable thereafter. They are also needed to bring more transparency to corporate borrowing and to rein in excessive lending to households. And many a social security system remains patently incompatible with demography. These reforms are not new. Some have been pending for years. COVID-19 has given them a new relevance. It would be an ironic silver lining if it took a global health crisis to get them done.

\section{NOTES}

1. The views expressed therein are those of the authors and do not necessarily reflect the views and policies of ADB, its Board of Governors or the governments they represent.

2. The ratio of debt to GDP, or "debt burden", as a proxy for debt sustainability and, more generally, for the fiscal health of the debtor has been questioned in recent literature. In the context of real interest rates that are close to zero, it has been argued that either the ratio of debt to the present value of GDP over an infinite horizon, or the ratio of interest payments to GDP, are better proxies. This book works with the traditional measure, for four reasons. First, real interest rates are currently close to zero only for public debt in advanced economies with no sovereign risk, but not elsewhere. In Asia, the phenomenon applies to Japan, to which a specific chapter is dedicated. Second, even in advanced economies, there is no certainty that real interest rates will remain close to zero in the future. The forces said to be pulling them down-increasing inequality, higher uncertainty, longer life expectancy, aging, changing corporate behaviors, technology-driven efficiency in the use of capital - are neither universal nor proven causes of the decline. Third, projecting GDP far into the future is fraught with uncertainty, especially in emerging and developing economies. And fourth, markets and credit-rating agencies still look at the ratio of debt to GDP to rate and price borrowing, a key input in the fiscal sustainability of most countries. For a leading proponent of the new proxies, see J. Furman and L. Summers (2020), A Reconsideration of Fiscal Policy in the Era of Low Interest Rates. Discussion Draft.

3. The 46 economies are grouped by subregions: Central Asia comprises Armenia, Azerbaijan, Georgia, Kazakhstan, the Kyrgyz Republic, Tajikistan, Turkmenistan, and Uzbekistan. East Asia is made up of Hong Kong, China; Mongolia; the PRC; the ROK; Mongolia; and Taipei,China. South Asia includes Afghanistan, Bangladesh, Bhutan, India, Maldives, Nepal, Pakistan, Sri Lanka. Southeast Asia covers Brunei Darussalam, Cambodia, Indonesia, the Lao People's Democratic Republic (Lao PDR), Malaysia, Myanmar, the Philippines, Singapore, Thailand, and Viet Nam. The Pacific includes the Cook Islands, Fiji, Kiribati, the Marshall Islands, the Federated States of Micronesia (FSM), Nauru, Niue, Palau, Papua New Guinea (PNG), Samoa, Solomon Islands, Timor-Leste, Tonga, Tuvalu, and Vanuatu.

4. Those 21 countries are Afghanistan, Bangladesh, Bhutan, Cambodia, Kiribati, the Kyrgyz Republic, the Lao PDR, Maldives, the Marshall Islands, the FSM, Myanmar, Nepal, Pakistan, PNG, Samoa, Solomon Islands, Tajikistan, Timor-Leste, Tonga, Tuvalu, and Vanuatu. 
5. Note that part of the deterioration is due to methodological changes to reflect the impact of frequent disasters triggered by natural hazards which worsened risk ratings for several island economies in the Pacific.

6. The economies are the PRC; Hong Kong, China; India; Indonesia; Japan; the ROK; Malaysia; Singapore; and Thailand.

7. ADB (2019), Meeting Asia's Infrastructure Needs. Manila. Accessed at: http://dx.doi.org/10.22617/ FLS168388-2.

8. The countries in question are Afghanistan, Armenia, Azerbaijan, Bangladesh, Bhutan, Cambodia, Fiji, Georgia, India, Indonesia, Kazakhstan, Kiribati, the Kyrgyz Republic, the Lao PDR, Malaysia, Maldives, the Marshall Islands, the FSM, Mongolia, Myanmar, Nauru, Nepal, Pakistan, PNG, the Philippines, the PRC, Samoa, Solomon Islands, Sri Lanka, Tajikistan, Thailand, Timor-Leste, Tonga, Turkmenistan, Tuvalu, Uzbekistan, Vanuatu, and Viet Nam.

9. In this publication, data for Myanmar were valid as of 14 December 2020 and may have changed thereafter because of major recent events affecting the country. 